\title{
Effect of heavy metals in recycled water used for household laundry on quality of cloth and washing machine
}

\author{
Thi Thu Nga Pham ${ }^{\mathrm{a}}$, Bandita Mainali ${ }^{\mathrm{a}}$, Huu Hao Ngo ${ }^{\mathrm{a}}$, Wenshan Guo ${ }^{\mathrm{a}}$, Andrzej Listowski ${ }^{\mathrm{b}}$, \\ Kelly O’Halloran ${ }^{\mathrm{c}}$, Clayton Miechel ${ }^{\mathrm{d}}$, Nigel Corby ${ }^{\mathrm{e}}$ \\ ${ }^{a}$ Faculty of Engineering and IT, University of Technology Sydney, Sydney, NSW 2007, \\ Australia \\ ${ }^{\mathrm{b}}$ Sydney Olympic Park Authority, Sydney Olympic Park, NSW 2127, Australia \\ ${ }^{c}$ Gold Coast Water, Gold Coast MC 9726, Australia \\ ${ }^{\mathrm{d}}$ Port Macquarie-Hastings Council, Port Macquarie, NSW 2444, Australia \\ ${ }^{\mathrm{e}}$ City West Water, Sunshine, VIC 3020, Australia \\ *Corresponding author: Email: h.ngo@uts.edu.au, Tel: +61(2) 95142745, Fax: + \\ 61(2)95142633, CB02.05, PO Box 123, Broadway, NSW 2007, Australia \\ Author contact: \\ Thithunga.pham@uts.edu.au, Tel: +61 (2) 95192620 \\ Bandita.Mainaly@student.uts.edu.au, Tel: +61 (2) 95199094 \\ Wenshan.Guo-1@uts.edu.au, Tel: +61 (2) 95192739 \\ Andrzej.Listowski@sopa.nsw.gov.au, Tel: 61 (2) +61 297147404 \\ KOHALLORAN@goldcoast.qld.gov.au, Tel: +61 755828718 \\ Clayton.Miechel@pmhc.nsw.gov.au \\ NCorby@ citywestwater.com.au
}

\begin{abstract}
Recycled water for washing clothes saves significant amount of potable water and hence has a great potential for sustainable urban water management. To date, there has been no official acceptance and very rare practice of use of recycled water for household laundry. This study investigates the effects of critical heavy metals ( $\mathrm{Pb}, \mathrm{Mn}, \mathrm{Fe}, \mathrm{Cu}$ and $\mathrm{Zn}$ ) on cloth quality and corrosive/scaling of washing machine to evaluate the feasibility of using recycled water for household laundry. The experimental data can be used for future recycled water quality guidelines. Five representative cloth materials namely polyester, satin, polycotton, denim and organic cotton were selected for washing in tap water and synthetic recycled water which contained different concentrations of heavy metals. Cloth durability, surface morphology and textile colour of washed cloth samples were measured to investigate the effects of heavy metals on quality of fabric. Langelier Saturation Index (LSI) was used as the indicator for predicting corrosive/scaling effects on washing machine. The results indicated that quality of fabrics after 50 wash cycles was found no change by recycled water when concentration of $\mathrm{Pb}$ and $\mathrm{Mn}<0.5 \mathrm{mg} / \mathrm{L}, \mathrm{Fe}<1 \mathrm{mg} / \mathrm{L}, \mathrm{Cu}<5 \mathrm{mg} / \mathrm{L}$ and $\mathrm{Zn}<30 \mathrm{mg} / \mathrm{L}$. Lower than the about values, the LSI indicated that recycled water would not led to any negative impact on washing machine.
\end{abstract}


Author keywords: fabric quality; heavy metals; Langelier Saturation Index; recycled water; washing machine.

\section{Introduction}

Water recycling as an alternative source has globally been recognised and has become a priority for the future sustainability. The Australian government is one of the four governments worldwide that have regulations for water recycling and have developed recycled water for a variety of purposes [1, 2]. Considerable amount of fresh water conservation has been achieved due to the use of recycled water in urban communities [3-6]. Dual reticulation systems have already been introduced in many suburbs in Australia and is likely to expand in many other suburbs (Rouse Hill and Newington in Sydney, Mawson Lakes and New Haven Village in Adelaide, Aurora and Marriott Waters in Melbourne, and Pimpama Coomera in Gold Coast) [7-9]. This may be attributed to the increasing and intensifying demands to develop water recycling capacity. For instance, the dual reticulation scheme at the Rouse Hill Development Area and Sydney Olympic Park Authority traditionally provide recycled water for outdoor garden use, toilet flushing and car washing at a total saving of approximately $35 \%$ of potable water use. Developed and proposed dual reticulation schemes in urban areas demand the substantial replacement of tap water with recycled water to ensure system optimisation and the sustainability of water supplies via more conservation of fresh water $[2,10]$. The world wide survey advocate that the volume of water used for laundry significantly influences the total water consumption of households. According to statistics on typical water usage in Sydney metropolitan households, laundry use consumes up to $20 \%$ of total water demand [11-13]. A significant reduction in household drinking water demand could therefore be achieved if the drinking quality water for clothes washing was replaced with recycled water. Therefore, washing machine as a new end use of recycled water in dual reticulation systems in urban cities has a great potential for sustainable urban water management $[2,14-17]$. However, the laundry use of recycled water has not been

sufficiently investigated and thus until today there is no sufficient evidence and supporting quality guidelines for this particular use [10, 12]. Moreover, the effects of various heavy metals present in recycled water on quality of clothes and washing machines have not been reported [11].

Recycled water sources range over a broad spectrum of chemical quality depending upon the source of the recycled water and the degree of treatment [2]. Some recycled waters contain slightly higher concentrations of heavy metals compared to potable water. Such water may be 
corrosive or aggressive in nature and thus can have effects like staining or dulling of cloth materials washed with that water. As a consequence, the cloth aesthetic appearance may be affected. Moreover, probable aesthetics and discolouration of laundry due to the use of recycled water was one of the most important concerns raised by the participants in many community surveys [12, 18-20]. Hurlimann and McKay [21] advocated that heavy metals in recycled water could deteriorate the cloth and washing machine. To encourage the use of recycled water for household laundry, the general community should be assured that the recycled water will not have negative impacts on cloth aesthetic appearance and durability.

Hence, the study was carried out for analysing the long term effects of heavy metals present in recycled water on the quality of cloths through measuring textile colour, surface morphology and tensile/tearing strength of the cloth samples washed by recycled water. In addition, heavy metals in water may be corrosive or aggressive in nature thus resulting into the scaling or corrosion problems. Thus, the effect of heavy metal concentrations in recycled water on washing machine was also determined through Langelier Saturation Index (LSI), an indicator of corrosive/scaling effects.

\section{Materials and methods}

\subsection{Materials}

In this research, synthetic recycled water was used. It was prepared by dissolving separately five heavy metals (Manganese $(\mathrm{Mn})$, Copper $(\mathrm{Cu})$, Zinc $(\mathrm{Zn})$, Iron $(\mathrm{Fe})$ and Lead $(\mathrm{Pb})$ into tap water. The electric conductivity (EC) of tap water and the cycle water were $200 \mu \mathrm{S} / \mathrm{cm}$ and $2000 \mu \mathrm{S} / \mathrm{cm}$ respectively. The concentration variation was formulated according to a thumb rule of 20 times the normal availability of that element in normal drinking water as provided in World Health Organisation (WHO), Australia Drinking Water Guidelines and Environment Protection Agency (EPA) as well as in the recycled water supplied in some suburbs in Sydney [22-25]. The concentrations of different heavy metals in drinking water and synthetic water are summarized in Table 1. The general ranges of heavy metals present in actual wastewaters were $0.01-0.27 \mathrm{mg} / \mathrm{L}$ of $\mathrm{Zn}, 0.17-25 \mathrm{mg} / \mathrm{L}$ of $\mathrm{Fe}, 0.001-3.3 \mathrm{mg} / \mathrm{L}$ of $\mathrm{Cu}$, $0.001-0.5 \mathrm{mg} / \mathrm{L}$ of $\mathrm{Pb}$ and $0.02-0.35$ of $\mathrm{Mn}[26-29]$.

Table 1 The guideline concentration range of heavy metals in drinking water and synthetic recycled water quality 
The most sensitive colour (white coloured fabrics) was selected for washing. Five types of representative cloth textile (polyester (Po), satin (S), polycotton (PoC), denim (D) and organic cotton (C)) were used for the tests. They were cut in size of $25 \times 20 \mathrm{~cm}$ for washing.

\subsection{Experimental methods}

The cloth samples were washed in top loading washing machine (Simpson SWT554, 5.5kg, 850prm). Each wash cycle was taken 45 minutes when using fast wash program, low water level and Eco rinse option. The temperatures of water used for washing and temperature of drying were $22^{\circ} \mathrm{C}$ and $125^{\circ} \mathrm{C}$ respectively. Omo detergent (main components: sodium sulphate, sodium linear alkybenzen, sodium tripolyphosphate, sodium carbonate, sodium silicate) was chosen as a washing powder. Washing of the selected cloth samples was performed for 50 wash cycles. Each wash bath were used about 50 pieces of cloth size of $25 \times 20 \mathrm{~cm}, 40$ litters of normal tap water or the synthetic recycled water containing heavy metals of various concentrations as well as about $20 \mathrm{~g}$ (half cup) of Omo detergent. After washing, the test samples were progressed for drying in dryer at $10^{\text {th }}$ and $50^{\text {th }}$ wash cycles. The dried samples were taken for analysing.

\subsection{Analytical methods}

Various testing methods have been adopted with the aim of analysing the durability and aesthetic appearance of cloth materials washed in synthetic recycled water. The cloth swatches were also washed in normal tap water in the same conditions and its quality after washing was also measured to evaluate the effect of heavy metals present in recycled water on cloth quality.

\subsubsection{Heavy metal analysis}

Heavy metals in samples were determined by Atomic Absorption Spectrophotometer (AAS) using a Control $\mathrm{AA}^{\mathrm{R}} 300$ (Analytic Jena).

\subsubsection{Colour measurements and colour difference calculation}

The change in colour of washed cloth samples were subjected to test in Spectrometer Perkin Elmer (LAMBDA 950) to check the aesthetic appearance of the cloth materials and the degree of dullness of the cloth material with the increased number of washing and increased concentration of targeted study elements. The colour of textile material is often one of most important features and colour is a subjective perception (individual/personal) [30, 31]. The 
human eye is more sensitive to some areas of colour and less sensitive to others. The CIELAB space is a uniform three dimensional space defined by the colorimetric coordinates $L^{*}, a^{*}$ and $b^{*}: L^{*}$ (lightness, ranging from 0 to 100 with higher numbers being brighter), $a^{*}$ (green-red coordinate), b* (blue-yellow coordinate) (Fig.1) [30]. The signs for these colour differences are $\Delta$ "delta" $\Delta \mathrm{L}^{*}, \Delta \mathrm{a}^{*}, \Delta \mathrm{b}^{*}$ and $\Delta \mathrm{C}^{*}$. The CIE $\mathrm{L}^{*} \mathrm{a}^{*} \mathrm{~b}^{*}$ space can calculate the distance between the points representing different colour stimuli, this distance is called the colour difference, usually designated as $\Delta$ Eab Three different formulas CIE76, CIE94 and CIEDE2000 $[33,34]$ are used to calculate colour difference. CIEDE2000 is the most complex formula but it is the most update and advanced way to determine colour difference. Therefore, CIEDE2000 was choose for estimating the colour differences of fabric before and after washing with metal solutions. The determination of CIEDE2000 was followed the methods of Luo at al. [33].

Fig.1 Colour plotting diagram for $\mathrm{L}^{*}, \mathrm{a}^{*}$ and $\mathrm{b}^{*}$.

\subsubsection{Scanning Electron Microscope (SEM)}

The surface morphology change in fabrics can be identified by scanning electron microscope (SEM). SEM helps to detect the surface morphology change at high spatial resolution. The

small pieces of cloth samples washed in tap water and in synthetic recycled water at $10^{\text {th }}$ wash and $50^{\text {th }}$ wash were given to test in SEM.

\subsubsection{Tensile and tearing strength tests}

To investigate the effects of different heavy metal concentrations on cloth durability, tearing strength tests and tensile strength tests of the washed cloth samples were carried out using Instron $602210 \mathrm{kN}$ Universal Testing Machine according to the ASTM standards [35, 36]. The washed cloth samples were prepared according to the test standard as per ASTM and then applied for the tests. Firstly, the tensile and tearing strengths of original samples were measured. Similarly, tensile strengths of the same cloth samples washed in tap water and synthetic recycled water of various concentrations of heavy metals were then determined. Basically, the measurement of tensile and tearing strength of the samples at $10^{\text {th }}$ wash and 
$50^{\text {th }}$ wash were conducted. MINITAB 16 as a statistical tool was used and ANOVA One way test was applied for the significance analysis (Tukey's test $\mathrm{p}<0.05$ ).

\subsection{Langelier Saturation Index (LSI)}

The effects on washing machine durability was investigated using Langelier Saturation Index $\left(\mathrm{LSI}=\mathrm{pH}_{\mathrm{calc}}-\mathrm{pH}_{\mathrm{msr}}\right)$ method. It is the pioneer and popular method for prognosticating the corrosive and scale forming tendency of the aqueous solutions [37, 38].

\section{Results and discussion}

\subsection{Colour difference}

The aesthetic appearance of the cloth is highly influenced by its colour. The changing of fabric colour is most sensitive issue for user. The change in aesthetic appearance of the cloth materials and the degree of dullness of the cloth material with the increased number of washing cycles in heavy metals solutions is measured by the colour difference. It is obvious that some changes in colour was brought about due to the numbers of washing of cloth in difference concentrations of heavy metals. Figs. 2 and 3 show the difference in $\Delta \mathrm{L}^{*}, \Delta \mathrm{a}^{*}$, $\Delta \mathrm{b}^{*}$ and $\Delta \mathrm{C}^{*}$ of 5 kinds of cloth samples washed in tap water and synthetic recycled water after 10 washing cycles $\left(\Delta \mathrm{L}^{*}=\right.$ difference in lightness/darkness, value $+=$ lighter, value $-=$ darker; $\Delta \mathrm{a}^{*}=$ difference on red/green axis, value $+=$ redder, $-=$ greener; $\Delta \mathrm{b}^{*}=$ difference on yellow/blue axis, value $+=$ yellower, $-=$ bluer; $\Delta C^{*}=$ difference in chroma,$+=$ brighter $-=$ duller). The figures revealed that the change in colour depends upon the cloth material and type and concentration of heavy metals solutions.

Fig. 2 shows the change in colour of cloth samples in terms of $\Delta \mathrm{L}$ after being washed in heavy metals solutions. As expected, the increase of heavy metal concentration led to increase of absolute values of $\Delta \mathrm{L}$. However, all cloth samples were only visibly observed to be darker after washing in synthetic recycled water contained $\mathrm{Fe}, \mathrm{Zn}$ and $\mathrm{Pb}$ concentrations higher than $1 \mathrm{mg} / \mathrm{L}, 30 \mathrm{mg} / \mathrm{L}$ and $0.05 \mathrm{mg} / \mathrm{L}$ respectively.

Fig. 2 The change in colour of cloth samples after 10 washing cycles in terms of $\Delta \mathrm{L}^{*}$

Fig. 3 shows the difference in $\Delta \mathrm{a}^{*}$ (red/green), $\Delta \mathrm{b}^{*}$ (yellow/blue) and $\Delta \mathrm{C}^{*}$ (bright/dull) of 5 kinds of cloth samples washed in tap water and recycled water after 10 washing cycles. Results revealed that only with the $\mathrm{Cu}$ concentration in the synthetic recycled water of more than $20 \mathrm{mg} / \mathrm{L}$, cloth samples were visibly observed to be greener than that washed by tap water $\left(\Delta \mathrm{a}^{*}\right.$ values was nearly -2 , Fig. 3a). The cloth samples washed in Fe solution is more 
yellowish $\left(\Delta b^{*}\right.$ positive $)$ and the levels of yellowness depends on concentration of $\mathrm{Fe}$ in solutions (Fig. 3b). Visible yellowness was observed when the Fe concentration was 5mg/L. The Fe concentration of $5 \mathrm{mg} / \mathrm{L}$ also led to significant duller for denim and satin (Fig. 3c).

Fig. 3 The change in colour of cloth samples after 10 washing cycles in term of $\Delta a^{*}, \Delta b^{*}$ and $\Delta \mathrm{C}^{*}$

Delta $E^{*}$ : There were some changes in colour of fabric in term of $\Delta \mathrm{L}^{*}, \Delta \mathrm{a}^{*}, \Delta \mathrm{b}^{*}$ and $\Delta \mathrm{C}^{*}$ but the significant difference between cloth washed with tap water and synthetic recycled water should be based on $\Delta \mathrm{E}^{*}$. The colour difference is considered a significant difference when the $\Delta \mathrm{E}^{*}$ is more than 2 [39]. Table 2 shows the difference in colour of cloth samples at different concentrations of heavy metals after 10 and 50 wash cycles. The results showed that the change in colour of cloth samples was difference depends on cloth materials and heavy metals concentrations.

In general, the highest value of $\Delta \mathrm{E}^{*}$ values for satin cloth samples washed in heavy metals $(\mathrm{Fe}=5 \mathrm{mg} / \mathrm{L})$ are up to 5.9 which concluded that the colour of satin was obvious difference with one washed in tap water. When synthetic recycled water contained more than $1 \mathrm{mg} / \mathrm{L}$ of $\mathrm{Pb}$ and $\mathrm{Fe}, 2 \mathrm{mg} / \mathrm{L}$ of $\mathrm{Mn}, 15 \mathrm{mg} / \mathrm{L}$ of $\mathrm{Cu}$ and $30 \mathrm{mg} / \mathrm{L}$ of $\mathrm{Zn}, \Delta \mathrm{E}^{*}$ value for satin after wash cycles laid in the range of 2-3.5 confirming that there was medium difference between the colours of the satin washed in tap water and the one washed in the synthetic recycled water. Colour of satin was significant different when washed in synthetic recycled water contained $5 \mathrm{mg} / \mathrm{L}$ of Fe. Denim exhibited the change in colour when it was washed with $5 \mathrm{mg} / \mathrm{L}$ and 20 $\mathrm{mg} / \mathrm{L}$ of $\mathrm{Fe}$ and $\mathrm{Cu}$ respectively $\left(\Delta \mathrm{E}^{*}>2\right)$. The colour of cotton cloth was found to be changed when concentration of more than $15 \mathrm{mg} / \mathrm{L}$ of $\mathrm{Cu}$ and $0.5 \mathrm{mg} / \mathrm{L}$ of $\mathrm{Mn}$ was applied in synthetic recycled water. Polycotton and polyester at 10 wash cycles for all heavy metal solutions (except Fe) were only slight change in colour which is invisible in compared with those washed in tap water $\left(\Delta \mathrm{E}^{*}\right.$ values $\left.<2\right)$. The experimental results also show that the present of $\mathrm{Zn}$ and $\mathrm{Pb}$ in synthetic recycled water even at high concentration (up to $60 \mathrm{mg} / \mathrm{L}$ of Zn) led to no significant change in colour after 50 wash cycles for those cloth samples (Table 2).

Table 2. The change in colour in delta $E^{*}(\Delta E 2000)$ at different concentration of heavy metals in water in comparison with tap water after 10 (10th) and 50 (50th) wash cycles 
In conclusion, heavy metals in water used for washing machine can have affected on cloth's colour. Fe concentration more than $1 \mathrm{mg} / \mathrm{L}$ in water made cloths become darker, duller and more yellowish. Moreover, recycled water contained more than $15 \mathrm{mg} / \mathrm{L}$ of $\mathrm{Cu}$ made the cloths not only greener, bluer but also duller. Although $\mathrm{Zn}$ and $\mathrm{Pb}$ in water solution made cloths darker and bluer but the change in colour is not significant. The heavy metals concentration in water at lower than $0.5 \mathrm{mg} / \mathrm{L}$ of $\mathrm{Mn}$ and $\mathrm{Pb}, 1 \mathrm{mg} / \mathrm{L}$ of $\mathrm{Fe}, 10 \mathrm{mg} / \mathrm{L}$ of $\mathrm{Cu}$ and $30 \mathrm{mg} / \mathrm{L}$ of $\mathrm{Zn}$ are considered safe for cloth in terms of change in colour.

\subsection{Change in surface morphology of fabric sample}

The scanning electron microscope (SEM) was used to investigate the change in surface morphology of fabric after being washed in synthetic recycled water contained different concentrations of heavy metals.

\section{Effect of $C$ u solution}

Fig. 4 shows the SEM images of denim after 10 wash cycles in tap water (Fig. 4a) and synthetic recycled water contained $\mathrm{Cu}$ concentration of $2,5,10,15$, and 20mg/L (Fig. $4 \mathrm{~b}, \mathrm{c}, \mathrm{d}, \mathrm{e}, \mathrm{f})$. It was found that the cloths after being washed with tap water had no change in surface morphology. However, the surface morphology of cloth samples washed by high concentration of $\mathrm{Cu}$ of $10 \mathrm{mg} / \mathrm{L}$ were changed notably. It indicates that the concentration of $\mathrm{Cu}$ of more than $10 \mathrm{mg} / \mathrm{L}$ could cause damages in surface morphology of cloth samples.

Fig. 4 Denim (1000x) after 10 wash cycles in tap water and $\mathrm{Cu}$ concentration of 2, 5, 10, 15, $20 \mathrm{mg} / \mathrm{L}$

Similarly, comparison of the images of all cloth samples were carried out and finally concluded that lower than $10 \mathrm{mg} / \mathrm{L}$ of $\mathrm{Cu}$ are safe for washing cloth in terms of surface of fabric. Event, the images of satin indicated that there was only slightly change in the surface morphology of the cloth material after washing by $\mathrm{Cu}$ synthetic recycled water at all concentrations. The reason may be because the satin fibre is more smooth and homogeneous in appearance in the original stage than in denim.

\section{Effect of Fe solution}

The SEM results show that the surface morphology of cloth samples was not affected if they were washed in tap water and Fe concentration of less than $1 \mathrm{mg} / \mathrm{L}$. However, cotton samples washed with concentration higher than $1 \mathrm{mg} / \mathrm{L} \mathrm{Fe}$ solution were observed to have some damages. Similar results were observed with most of the cloth types washed for 10 wash 
cycles in Fe solutions. Therefore, it is summarised that up to $1 \mathrm{mg} / \mathrm{L}$ of Fe solution, there is no negative impacts on the surface morphology of fabric.

\section{Effect of $\mathrm{Pb}, \mathrm{Mn}$ and $\mathrm{Zn}$ solution}

The images of most cloth samples washed by $\mathrm{Pb}, \mathrm{Mn}$ and $\mathrm{Zn}$ solutions at all concentrations after 10 wash cycles revealed that there was no change in surface morphology of fabric. However, images of cotton cloth at $50^{\text {th }}$ wash cycles showed some distinct change in surface morphology at $2 \mathrm{mg} / \mathrm{L}$ of $\mathrm{Pb}$ and $\mathrm{Mn}$ and $60 \mathrm{mg} / \mathrm{L}$ of $\mathrm{Zn}$. Therefore, under $1 \mathrm{mg} / \mathrm{L}$ of $\mathrm{Pb}, \mathrm{Mn}$, and $30 \mathrm{mg} / \mathrm{L}$ of $\mathrm{Zn}$ are considered safe in terms of surface morphology of fabric.

For further assurance, images of washed cloth samples in recommended values of $1 \mathrm{mg} / \mathrm{L}$ of $\mathrm{Pb}$, and $\mathrm{Mn}$ and $\mathrm{Fe} ; 10 \mathrm{mg} / \mathrm{L}$ of $\mathrm{Cu}$; and $30 \mathrm{mg} / \mathrm{L} \mathrm{of} \mathrm{Zn}$ were taken in SEM at 5000x. The images (Fig. 5) show that there was no change in the surface morphology of that fabric compared with the ones washed with tap water. Therefore, those doses had no impacts on fabric in terms of surface morphology.

Fig. 5 Polycotton (5000x) after 10 wash cycles of tap water (a), $1 \mathrm{mg} / \mathrm{L}$ of $\mathrm{Pb}, \mathrm{Fe}$ and $\mathrm{Mn}$ (b,c,d), $10 \mathrm{mg} / \mathrm{L}$ of $\mathrm{Cu}(\mathrm{e})$ and $30 \mathrm{mg} / \mathrm{L}$ of $\mathrm{Zn}(\mathrm{f})$

\subsection{Tensile and tearing strength test}

Fabric utility parameters most often depend on its mechanical properties. Tensile strength and tearing strength both are the most important strength parameters of cloth fibres exhibiting the durability of the cloth material [40]. The lifespan of a textile product is directly related to the number of wash cycles it can endure. The comparative study of tensile and tearing strengths of all types of cloth samples washed in tap water at different wash cycles $10^{\text {th }}$ and $50^{\text {th }}$ and the cloth samples washed in various concentrations of $\mathrm{Cu}$ and $\mathrm{Mn}$ at respective number of wash cycles were conducted.

The results of mean values of tensile strengths of cloth samples washed in various concentrations of aqueous solutions at $10^{\text {th }}$ wash cycles are summarized in Table 3 .

Table 3 shows that no significance difference in the tensile strengths of all cloth samples (except polyester) washed in tap water, $1 \mathrm{mg} / \mathrm{L}, 2 \mathrm{mg} / \mathrm{L}$ and $5 \mathrm{mg} / \mathrm{L}$ of $\mathrm{Cu}$ solutions was observed. However, the $\mathrm{Cu}$ concentration in synthetic recycled water of more than $5 \mathrm{mg} / \mathrm{L}$ could result in significant change in tensile strength of Polyester. (Tukey's test $p<0.05$ ). It is summarised that $(\leq 5 \mathrm{mg} / \mathrm{L})$ of $\mathrm{Cu}$ solutions, there is no negative impacts on the tensile strengths of cloth samples compared to that of tap water. 
Table 3 further indicates that, significance difference is only observed in tensile strengths of polyester, satin, and polycotton washed in $1 \mathrm{mg} / \mathrm{L}$ and above concentration of $\mathrm{Mn}$ solutions compared to the same cloth samples washed in tap water for 10 wash cycles. No significant reduction in tensile strength for almost all cloths (except Polyester) was observed at $0.5 \mathrm{mg} / \mathrm{L}$ of $\mathrm{Mn}(\leq 0.5 \mathrm{mg} / \mathrm{L})$. Hence, summarizing $0.5 \mathrm{mg} / \mathrm{L}$ of $\mathrm{Mn}$ is recommended safe in terms of tensile strength.

Table 3 Tensile strengths with $\mathrm{Cu}$ and $\mathrm{Mn}$, washing at $10^{\text {th }}$ wash cycle

The results of mean values of tearing strengths of cloth samples washed in various concentrations of synthetic recycle water at $10^{\text {th }}$ wash cycles are summarized in Fig. 6.

Fig. 6 Tearing strength of cloth samples washed in various concentration of $\mathrm{Cu}$ and $\mathrm{Mn}$ solutions and tap water.

The results from the Fig. 6(a) further indicated that there was no significance difference in the tearing strengths of cotton and satin washed in tap water and $\mathrm{Cu}$ concentration. There was not much change in tearing strength of the denim, polycotton and polyester cloth samples washed in $\mathrm{Cu}$ concentrations 1, 2 and $5 \mathrm{mg} / \mathrm{L}$ compared to those cloths washed in tap water. However, at $\mathrm{Cu}$ concentration of more than $10 \mathrm{mg} / \mathrm{Ll}$, the change in the tearing strength of these 3 types of cloths compared to those washed in tap water was significant. Therefore, $5 \mathrm{mg} / \mathrm{L}$ of $\mathrm{Cu}$ is recommended to be the maximum allowable concentration in terms of tearing strength of denim.

Tearing strength study of cloth samples washed in Mn solutions (Fig. 6b) revealed that up to $1 \mathrm{mg} / \mathrm{l}$ of $\mathrm{Mn}$, there was not much change in tearing strength of the cloth samples washed in various Mn concentrations compared to cloth samples washed in tap water.. However, above $1 \mathrm{mg} / \mathrm{L}$ of $\mathrm{Mn}$ concentration at $2 \mathrm{mg} / \mathrm{L}$ of $\mathrm{Mn}$, the change in the tearing strength of the cloth compared to the one washed in tap water was significant (about $11 \%$ ). Therefore, $1 \mathrm{mg} / \mathrm{L}$ of $\mathrm{Mn}$ is recommended to be the maximum allowable concentration in terms of tearing strength of cloth samples.

\subsection{Langelier Saturation Index (LSI)}

Langelier saturation index (LSI) is the pioneer method for prognosticating the corrosive and scale-forming behaviour of water [38]. This index provides a simple criterion by which the likelihood of corrosion or scaling can be predicted. LSI is a numerical index which is defined as the difference between the pHcalc, calculated from the data of the chemical analysis, and the $\mathrm{pHmsr}$ measured. 


$$
\begin{aligned}
& \mathrm{LSI}=\mathrm{pH}_{\mathrm{calc}}-\mathrm{pH}_{\mathrm{msr}} \\
& \mathrm{pH}_{\mathrm{msr}}=(9.3+A+B)-(C+D)
\end{aligned}
$$

where:

$$
\begin{aligned}
\circ & \mathrm{A}=(\log 10[\mathrm{TDS}]-1) / 10 \\
\circ & \mathrm{B}=-13.12 \times \log 10\left(\mathrm{~T}^{\circ} \mathrm{C}+273\right)+34.55 \\
\circ & \mathrm{C}=\log 10\left[\mathrm{Ca}^{2+} \text { as } \mathrm{CaCO}_{3}\right]-0.4 \\
\circ & \mathrm{D}=\log 10\left[\text { alkalinity as } \mathrm{CaCO}_{3}\right]
\end{aligned}
$$

If the LSI $<0$ (negative value), the water causes corrosion of steel. If the LSI $=0$, the water is neutral and stable and does not cause corrosion or scaling. As the LSI is rather a qualitative than a quantitative characteristic, its being equal to zero should not be taken too literally. Thus, the values of the LSI in the range of -0.5 to +0.5 should be taken as "zero". When the LSI > 0 (positive value), the water can cause scaling on the surfaces of pipelines, heatexchangers and other technological equipment [38].

As expressed in the above equations for calculating the LSI of any water sample, the total dissolved solid (TDS), the temperature (T), pH, the calcium hardness and the total alkalinity of the water sample were analysed. The LSI results are shown in Table 4.

Table 4 LSI of synthetic recycled water of various concentrations of heavy metals.

As can be seen in Table 4, it is clear that the LSI value was in range of -0.5 to +0.5 for the concentrations of $5 \mathrm{mg} / \mathrm{L}$ of $\mathrm{Cu}, 2 \mathrm{mg} / \mathrm{L}$ of $\mathrm{Pb}$ and $\mathrm{Mn}, 1 \mathrm{mg} / \mathrm{L}$ of $\mathrm{Fe}$ and $30 \mathrm{mg} / \mathrm{L}$ of $\mathrm{Zn}$ in water. That the synthetic recycled water up to those concentrations of heavy metals is balanced and suitable to use in washing machine without any harsh impact. However, at higher those concentrations, the LSI values were not in the range of +0.5 to -0.5 , showing that the water is not balanced and has slight potential to corrosion. Hence, it is suggested that $5 \mathrm{mg} / \mathrm{L}$ of $\mathrm{Cu}, 2 \mathrm{mg} / \mathrm{L}$ of $\mathrm{Pb}$ and $\mathrm{Mn}, 1 \mathrm{mg} / \mathrm{L}$ of $\mathrm{Fe}$ and $30 \mathrm{mg} / \mathrm{L}$ of $\mathrm{Zn}$ in recycled water can be the maximum value of those heavy metals in terms of washing machine durability.

\subsection{Visual Inspection of washing machine}

Long term visual inspection of washing machine was carried out after 50 wash cycles of cloth samples in 25 different concentrations of 5 heavy metals (more than 600 wash cycles) were carried out. The observation revealed no signs of corrosion or stain on the washing machine.

\section{Conclusions}


Conclusively, the level of change in colour and quality of cloth samples depended on cloth materials and heavy metal concentrations. From the effect of metals in recycled water, the maximum allowable value of heavy metals in recycled water used for household laundry was successfully determined and recommended for establishing the guideline. The lowest concentration of heavy metals in recycled water for laundry were found to be: $0.5 \mathrm{mg} / \mathrm{L}$ of $\mathrm{Pb}$ and $\mathrm{Mn}, 1 \mathrm{mg} / \mathrm{L}$ of $\mathrm{Fe}, 5 \mathrm{mg} / \mathrm{L}$ of $\mathrm{Cu}$ and $30 \mathrm{mg} / \mathrm{L}$ of $\mathrm{Zn}$. It is important to note that these values of heavy metals have been suggested only considering their effects on cloth durability, aesthetic aspects of cloth quality and durability of washing machine.

\section{Acknowledgement}

This work was funded by Australian Research Council (ARC) Industry Linkage Grant (LP100100494). The authors acknowledge the supports from Port Macquarie Hasting Council, Allconnex Water, City West Water and Sydney Olympic Park Authority.

\section{References}

[1] A.N. Angelakis, L. Bontoux, V. Lazarova, Challenges and prospectives for water recycling and reuse in EU countries, Water Sci. Technol.: Water Supply, 3(4) (2003) 5968.

[2] J.C. Radcliffe, Future directions for water recycling in Australia, Desal., 187 (2006) 77 87.

[3] D. Tillman, T.A. Larsen, C. Pahl-Wostl, W. Gujer, Modelling the actors in water supply systems, Water Sci. Technol., 39(4) (1999) 203-11.

[4] M. Ogoshi, Y. Suzuki, T. Asano, Water reuse in Japan, Water Sci. Technol., 43 (2000) 17-23.

[5] B. Janosova, J. Miklankova, P. Hlavinek, T. Wintgens, Drivers for wastewater reuse: Regional analysis in the Czech Republic. In: Khan SJ, Mustan MH, Schafer AI, editors. Integrated concepts in water recycling. University of Wollongong, Australia; 2005. p. $331-42$.

[6] Y. Zhang, A.Grant, A.Sharma, D. Chen andL.Chen, Alternative water resources for rural residential development in Western Australia. Water Resour. Manage., 24(1) (2010) 2536. 
[7] J.C. Radcliffe, Water recycling in Australia. A review undertaken by the Australian academy of technological sciences and engineering. Victoria, Australia. 2004. Available from: http://www.atse.org.au/resourcecentre/func-startdown/136/2004

[8] A. Hurlimann, Community attitudes to recycled water use - An urban Australian case study, part 2. Research Rep. No. 56, Cooperative research centre for water quality and treatment. 2008.

[9] R.M. Willis, R.A. Stewart, P.R. Williams, C.H. Hacker, S.C. Emmonds, G. Capati, Residential potable and recycled water end uses in a dual reticulated supply system, Desal., 272 (1-3) (2011) 201-211.

[10] B. Mainali, H.H. Ngo, W. Guo, T.T.N. Pham, A. Johnston, Feasibility assessment of recycled water use for washing machines in Australia through SWOT analysis. Resour. Conser. Recyc., 56 (2011) 87-91.

[11] H.H. Ngo, H. Chuang, W.S. Guo, D.P. Ho, T.T.N. Pham, A. Johnston, R. Lim, A. Listowski, Resident's strategy survey on a new end use of recycled water in Australia. Desal. Wat. Treat., 11 (2009), 93- 7.

[12] T.T.N. Pham, H.H. Ngo, W. Guo, H.P. D. Dang, B. Mainali, A. Johnston, A. Listowski, Responses from general community to the possible use of recycled water from washing machines: A case study in Sydney, Australia, Resour. Conser. Recyc., 55 (2011) 535-40.

[13]J.M. Anderson, Integrating recycled water into urban water supply solutions, Desal., 187 (2006) 1-9.

[14] A. Dixon, D. Butler, A. Fewkes, Water saving potential of domestic water reuse systems using greywater and rainwater in combination, Water. Sci. Technol., 39(5) (1999) 25-32.

[15] N. Tangsubkul, P. Beavis, S.J.Moore, S. Lundie, T.D. Waite, Life cycle assessment of water recycling technology. Wat. Resour. Manage., 19 (2005) 521-537

[16] R.K. Henderson, A. Baker, K. Murphy, A. Hambly, R.M. Stuetz, S.J. Khan, Fluorescence as a potential monitoring tool for recycled water systems: A review. Water Res., 43 (2009) 863-81.

[17] S. Fontdecaba, J.A. Sánchez-Espigares, L. Marco-Almagro, X. Tort-Martorell, F. Cabrespina, J. Zubelzu, An approach to disaggregating total household water consumption into major end-uses. Water Resour. Manage., 27 (2013) 2155-2177

[18] S. Dolnicar and C. Saunders, Recycled water for consumer markets - a marketing research review and agenda. Desal., 187 (2006) 203-14.

[19] A.C. Hurlimann, J.M. McKaym, Urban Australians using recycled water for domestic non-potable use-An evaluation of the attributes price, saltiness, colour and odour using conjoint analysis, Environ. Manage. J., 83(1) (2007) 93-104.

[20] N. Roseth, Community views on recycled water - the impact of information. Research report no. 48, Cooperative Research Centre for water quality and treatment. Salisbury, South Australia, 2008.

[21] A.C. Hurlimann, J.M. McKay, What attributes of recycled water make it fit for residential purposes? The Mawson Lakes experience, Desal., 187(1-3) (2006) 167-177.

[22] WHO (World Health Organisation). Guidelines for drinking water quality, Third Edition, Volume 1, Recommendations 2004. Available from: http://www.who.int/water sanitation health/dwq/GDWQ2004web.pdf 
[23] ADWG (Australian Drinking Water Guidelines). Australian guidelines for drinking water 6, National quality water management strategy. National Health and Medical Research Council and Natural Resource Management Ministerial Council 2004. Available from:

http://www.nhmrc.gov.au/_files_nhmrc/publications/attachments/adwg_11_06.pdf?q=pu blications/synopses/_files/adwg_11_06.pdf

[24] EPA (Environment Protection Agency). Edition of the Drinking Water Standards and Health Advisories. 2011. Available from:

http://water.epa.gov/action/advisories/drinking/upload/dwstandards2011.pdf

[25] M.V.Storey, Addressing aesthetic and technical issues associated with the use of recycled water in washing machine. Sydney Water, (2009). Available from:

http://www.sydneywater.com.au/Water4Life/InYourHome/

[26] M. Karvelas, A. Katsoyiannis, C. Samara, Occurrence and fate of heavy metals in the wastewater treatment process, Chemosphere 53 (2003) 1201-1210.

[27] B. Mansouri, M. Ebrahimpour, Heavy metals characteristics of wastewater stabilization ponds, American-Eurasian J. Agric. \& Environ. Sci., 10 (5) (2011) 763-768.

[28] M. Anim-Gyampo, A. Ntiforo, M. Kumi, Assessment of Heavy Metals in Waste-Water Irrigated Lettuce in Ghana: The Case of Tamale Municipality, J. Sustain. Develop., 5 (11) (2012) 93-102.

[29] A.S. Al-Farraj, M. Al-Sewailem, A. Aly, M. Al-Wabel, S. El-Maghraby, Assessment and heavy metal behaviors of industrial waste water: A case study of Riyadh city, Saudi Arabia, Proceedings Inter. Academy Ecolo. Environ. Sci., 3(3) (2013) 266-277

[30] R.G. Kuehni, Why CIELAB needs to be replaced for industrial color difference calculation. Tex. Chem. Color., 31 (1999) 11-17.

[31] B. Becerir, Assessment of the results of different color difference formulae under different illuminates by wash fastness tests, Fibres Polymers, 12 (2011) 946-956.

[32] W.G. Kuo, M.R. Luo, H.E. Bez, Various chromatic-adaptation transformations tested using new colour appearance data in textiles. Color Res. Appl., 20(5) (1995) 313-327.

[33] M.R. Luo, G. Cui, B. Rigg, The development of the CIE 2000 colour difference formula CIEDE 2000. Color. Res. Appl., 26 (2001) 340-346.

[34] K.J. Kim, H.G. Ahn, A study on utilization of stainless steel wire cloth as a catalyst support. J. Indus. Eng. Chem., 18(2) (2012) 668-673

[35] ASTM Standard D 5035-95, Standard Test Method for breaking force and elongation of textile fabrics (Strip method), ASTM International, West Conshohocken, PA, 2006.

[36] ASTM D2261 - 07ae1, Standard Test Method for tearing strength of fabrics by the tongue (Single Rip) procedure (Constant-Rate-of-Extension Tensile Testing Machine), ASTM International, West Conshohocken, PA, 2006.

[37] S.A. Imran, J.D. Dietz, G. Mutoti, J.S. Taylor, A.A. Randall, Modified Larsons Ratio Incorporating temperature, water age, and electroneutrality effects on Red water release, J. Env. Eng., 131(11) (2005) 1514-20.

[38] V.A. Prisyazhniuk, Prognosticating scale-forming properties of water, Appl. Ther. Eng., 27 (2007) 1637-41. 
[39] CIE, Colorimetry $2^{\text {nd }}$ edn. Publication C.I.E. No. 15.2, Central Bureau of the Commission Internationale de L'Eclairage, Vienna, 1986.

[40] B. Witkowska, I. Frydrych, Protective clothing - test methods and criteria of tear resistance assessment, Int. J. Sci. Tech., 17 (3/4) (2005) 242 - 52. 


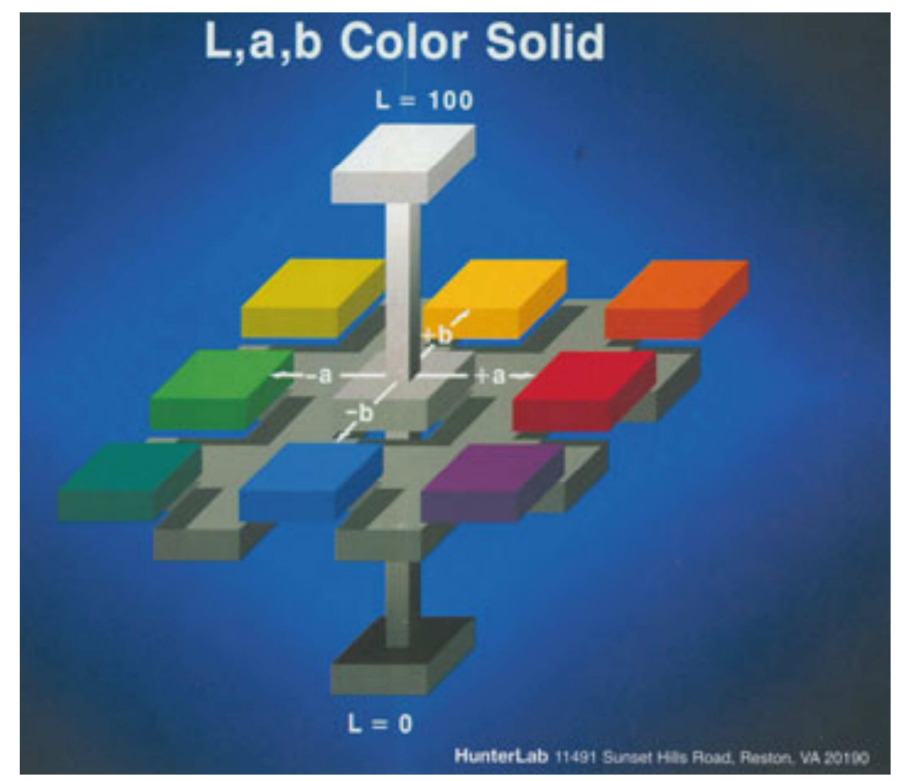

Fig.1 Colour plotting diagram for $\mathrm{L}^{*}, \mathrm{a}^{*}$ and $\mathrm{b}^{*}$. 


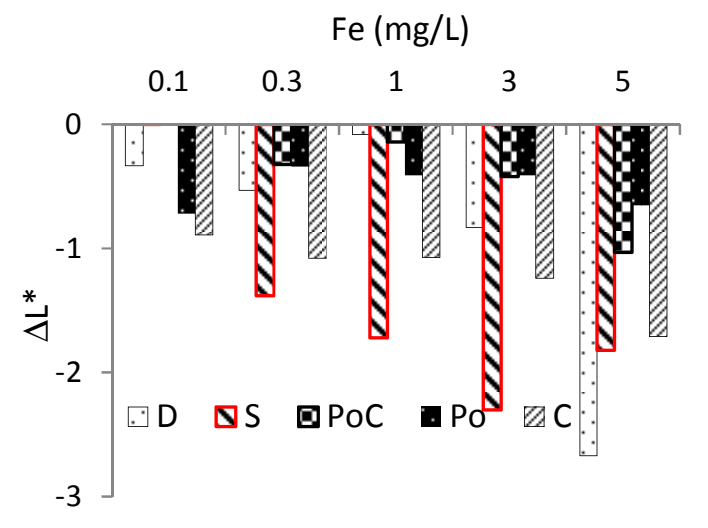

(a)

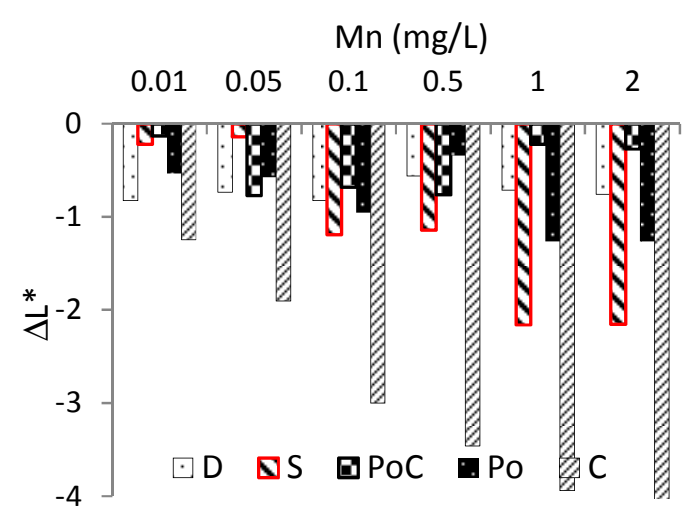

(c)

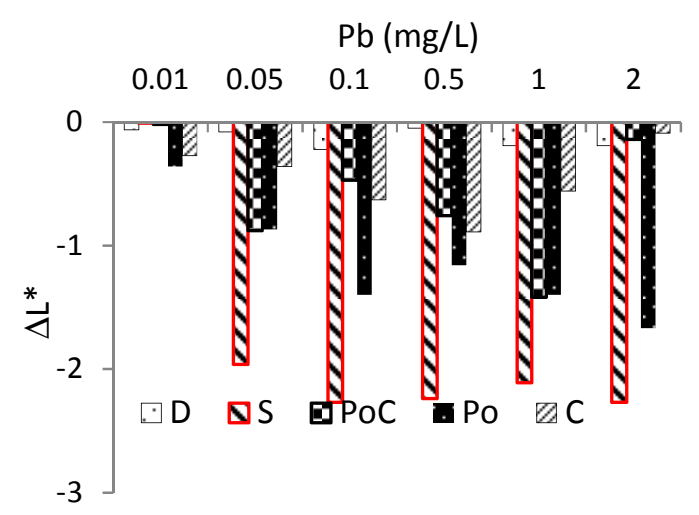

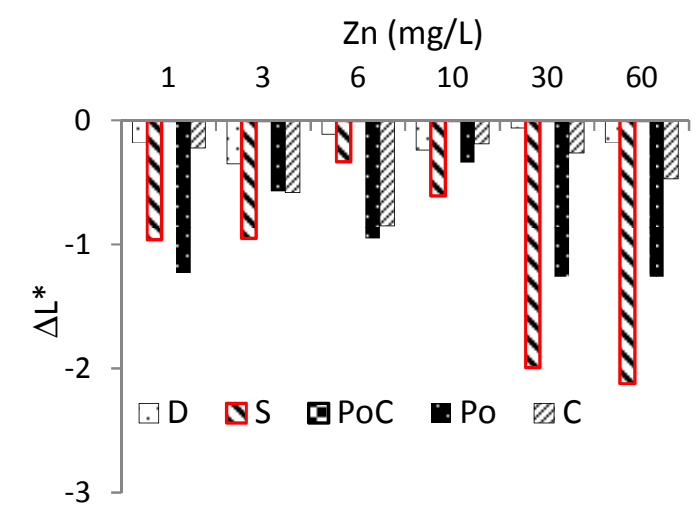

(b)

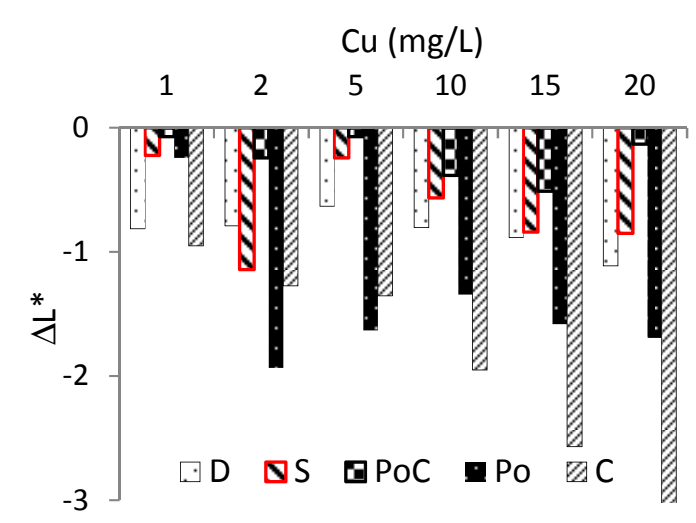

(d)

(e)

Fig. 2 The change in colour of cloth samples after 10 washing cycles in terms of $\Delta \mathrm{L}^{*}$ Note: $\Delta L^{*}=$ difference in lightness/darkness value $+=$ lighter, value $-=$ darker 


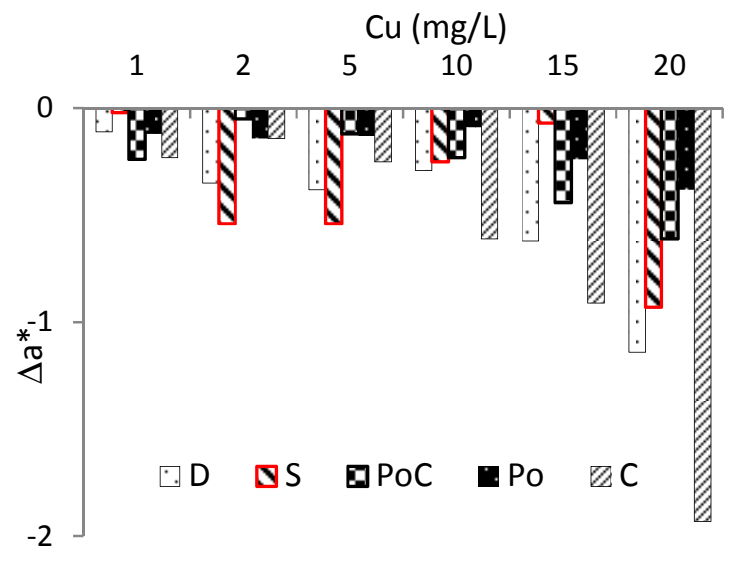

(a)

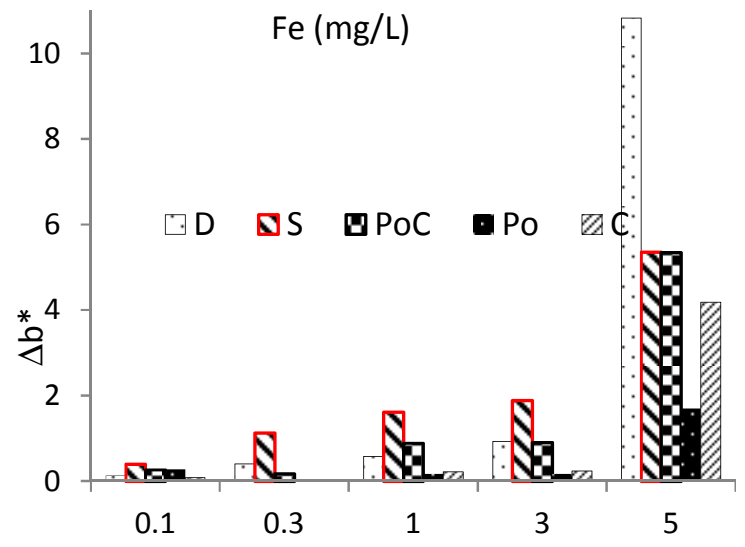

(b)

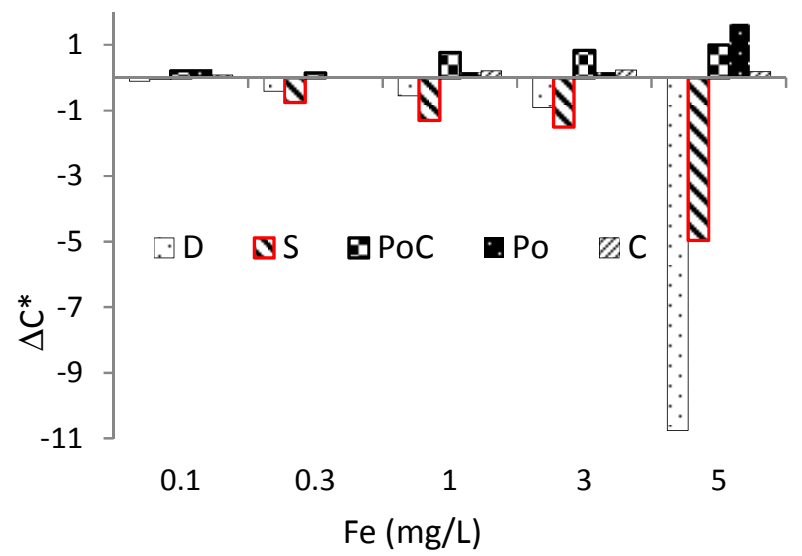

(c)

Fig. 3 The changing colour of clothe samples after 10 washing cycles in $\Delta \mathrm{a}^{*}, \Delta \mathrm{b}^{*}$ and $\Delta \mathrm{C}^{*}$

Note: $\quad \Delta a^{*}=$ difference on red/green axis, $+=$ redder,$-=$ greener;

$\Delta b^{*}=$ difference on yellow/blue axis, $+=$ yellower, $-=$ bluer;

$\Delta C^{*}=$ difference in chroma,$+=$ brighter $-=$ duller 


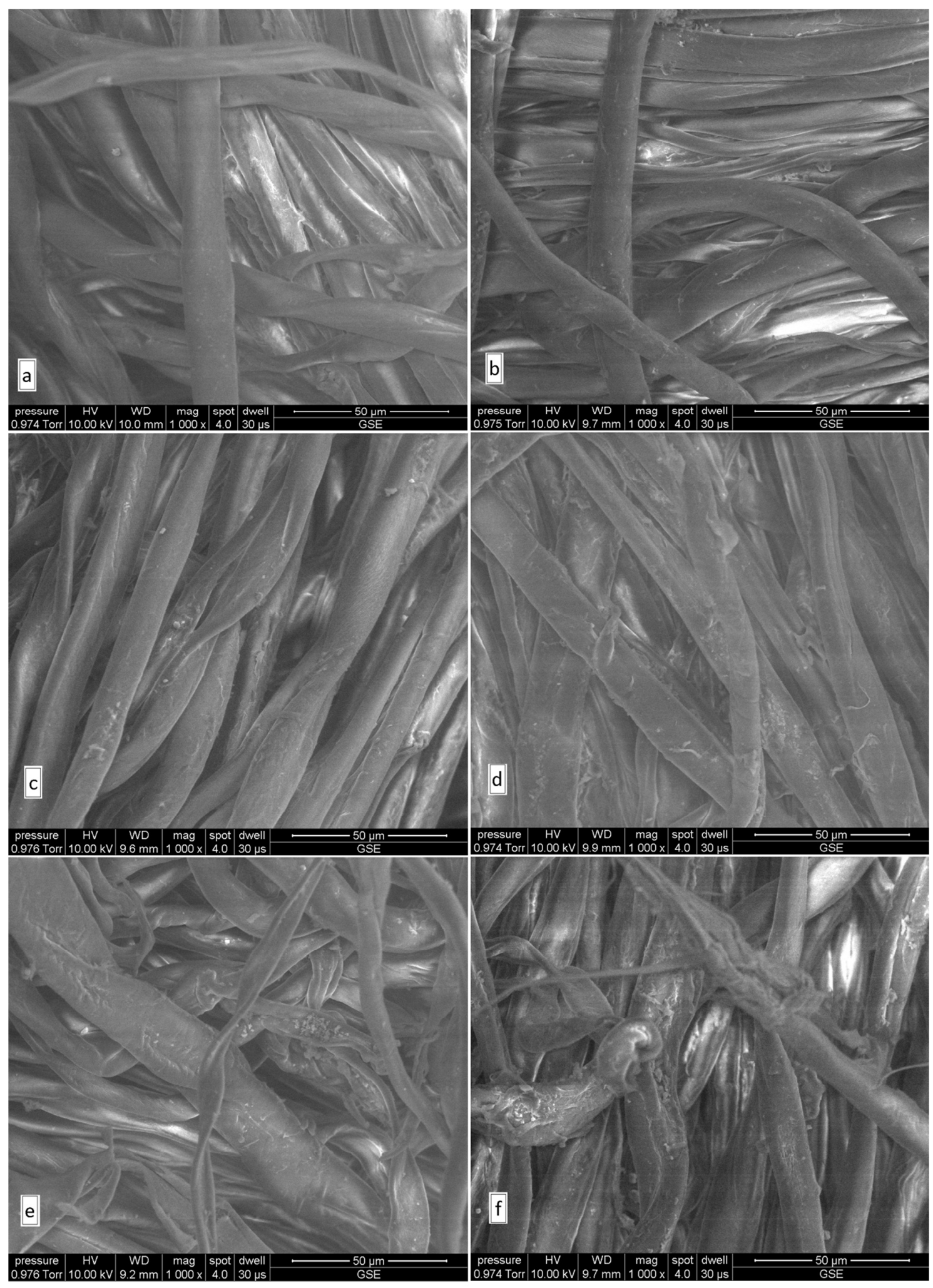

Fig. 4 Denim (1000x) after 10 wash cycles in tap water and $\mathrm{Cu}$ concentration at 2, 5, 10, 15, $20 \mathrm{mg} / \mathrm{L}$. 


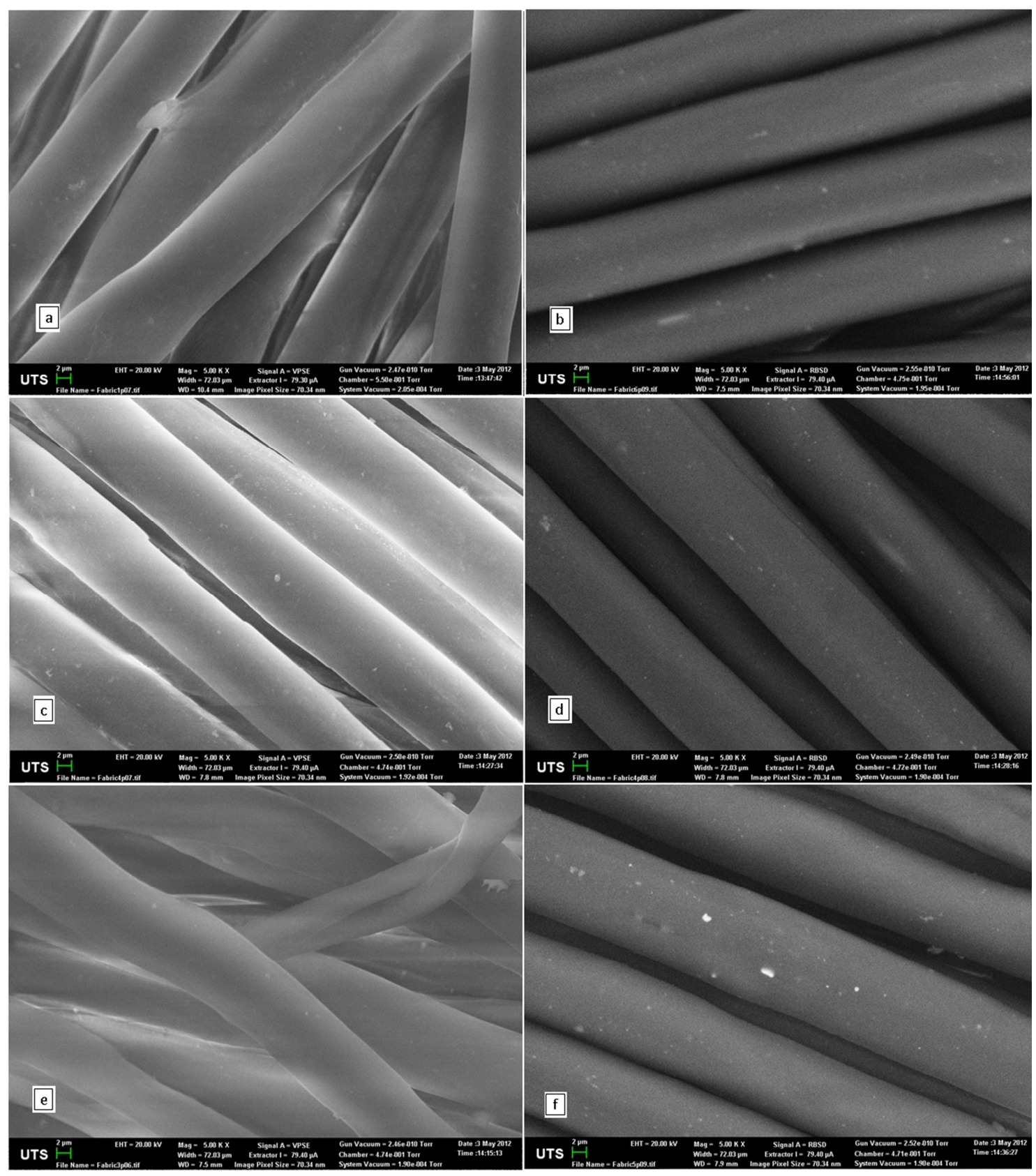

Fig. 5 Polycotton (5000x) after 10 wash cycles of tap water (a), $1 \mathrm{mg} / \mathrm{L}$ of $\mathrm{Pb}, \mathrm{Fe}$ and $\mathrm{Mn}$ (b,c,d), $10 \mathrm{mg} / \mathrm{L}$ of $\mathrm{Cu}(\mathrm{e})$ and $30 \mathrm{mg} / \mathrm{L}$ of $\mathrm{Zn}(\mathrm{f})$. 


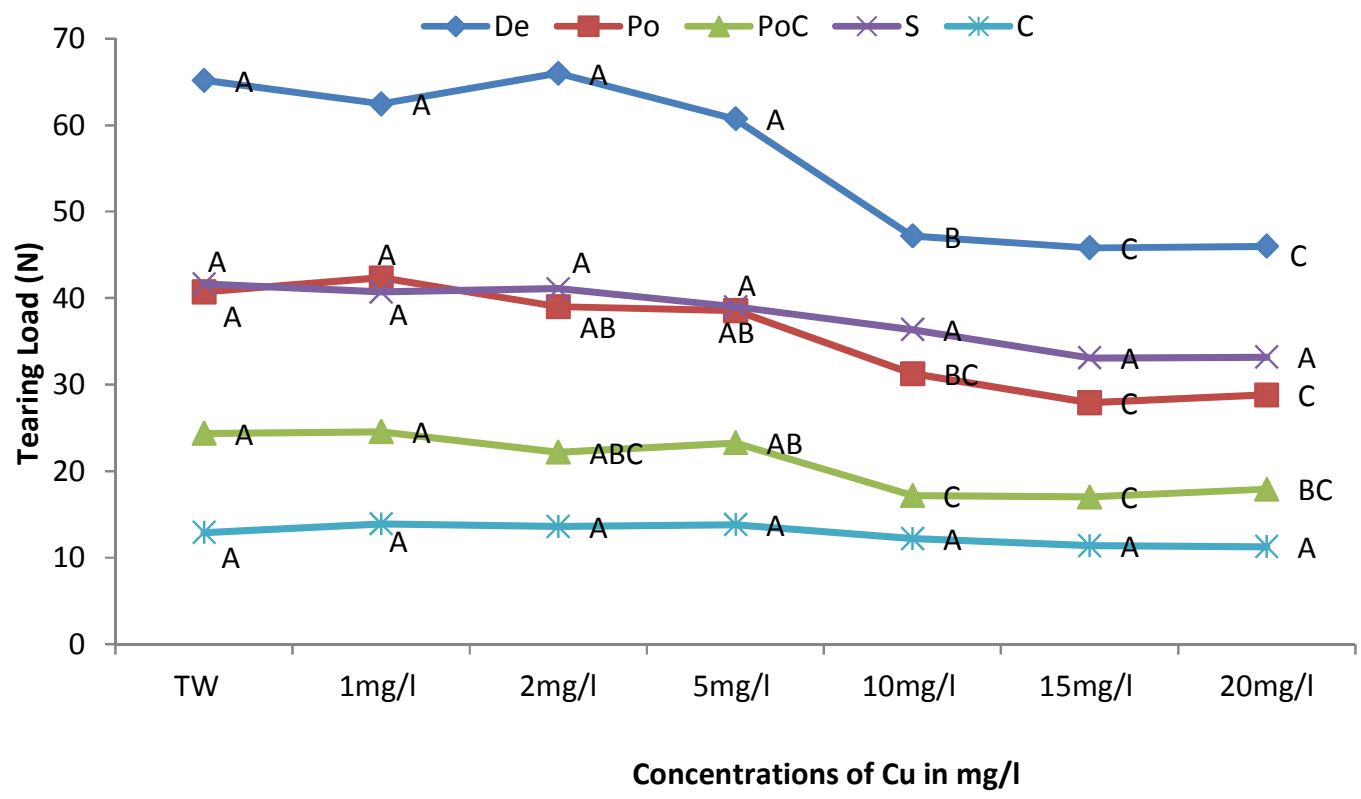

(a)

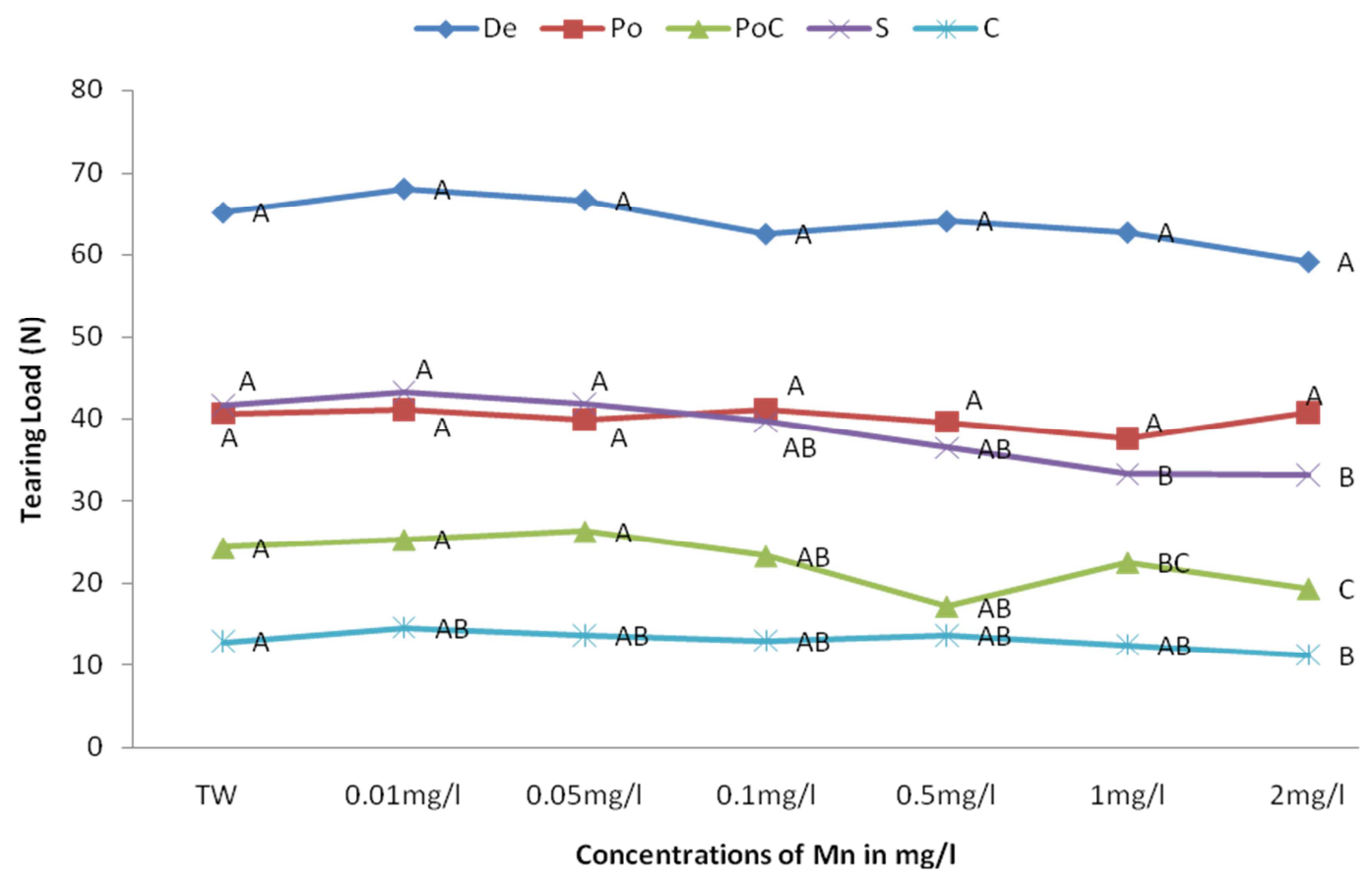

(b)

Fig. 6 Tearing strength of cloth samples washed in various concentration of $\mathrm{Cu}$ and $\mathrm{Mn}$ solutions and tap water

Note: A, B, C, D represents the group according to ANOVA-One way analysis (Tukey's test p<0.05). The points sharing the same alphabets represent no significant difference in tearing strength. 


\section{Table 1}

The guideline concentration range of heavy metals in drinking water and synthetic recycled water quality

\begin{tabular}{ccccc}
\hline $\begin{array}{c}\text { Heavy } \\
\text { metals }\end{array}$ & $\begin{array}{c}\text { WHO, 2004 } \\
(\mathbf{m g} / \mathbf{L})\end{array}$ & $\begin{array}{c}\text { ADWG, 2004 } \\
(\mathbf{m g} / \mathbf{L})\end{array}$ & $\begin{array}{c}\text { EPA, 2011 } \\
(\mathbf{m g} / \mathbf{L})\end{array}$ & $\begin{array}{c}\text { Synthetic recycled water } \\
(\mathbf{m g} / \mathbf{L})\end{array}$ \\
\hline $\mathrm{Fe}$ & 0.3 & 0.3 & 0.3 & $0.1-6$ \\
$\mathrm{Zn}$ & 3 & 3 & 3 & $1-60$ \\
$\mathrm{~Pb}$ & 0.01 & 0.01 & $\mathrm{NA}$ & $0.01-2$ \\
$\mathrm{Mn}$ & $0.05-0.4$ & $0.5-1$ & $\mathrm{NA}$ & $0.01-2$ \\
$\mathrm{Cu}$ & 2 & $1-2$ & 1.3 & $1-20$ \\
\hline
\end{tabular}




\section{Table 2}

The change in colour in delta $\mathrm{E}^{*}(\Delta \mathrm{E} 2000)$ at different concentration of heavy metals in water in comparison with tap water after $10\left(10^{\text {th }}\right)$ and $50\left(50^{\text {th }}\right)$ wash cycles

\begin{tabular}{|c|c|c|c|c|c|c|c|}
\hline $\begin{array}{l}\text { Heavy } \\
\text { metals }\end{array}$ & $\begin{array}{l}\text { No of } \\
\text { wash }\end{array}$ & $\begin{array}{c}\text { Con. } \\
\text { (mg/L) }\end{array}$ & Denim & Satin & Polycotton & Polyester & Cotton \\
\hline \multirow{6}{*}{$\mathrm{Fe}$} & & 0.1 & 0.3 & 0.4 & 0.5 & 0.6 & 0.7 \\
\hline & $10^{\mathrm{th}}$ & 0.3 & 0.5 & 1.5 & 0.3 & 0.3 & 0.8 \\
\hline & $10^{\text {th }}$ & 1 & 0.5 & 2.1 & 1.0 & 0.4 & 0.8 \\
\hline & $10^{\mathrm{th}}$ & 3 & 1.0 & 2.4 & 1.0 & 0.4 & 0.9 \\
\hline & $10^{\text {th }}$ & 5 & 3.2 & 5.0 & 2.3 & 1.7 & 1.1 \\
\hline & $50^{\text {th }}$ & 5 & 5.0 & 5.9 & 3.3 & 3.1 & 2.3 \\
\hline \multirow[t]{7}{*}{$\mathrm{Zn}$} & & 1 & 0.1 & 0.7 & 0.5 & 1.0 & 0.2 \\
\hline & $10^{\text {th }}$ & 3 & 0.2 & 1.2 & 0.4 & 0.5 & 0.4 \\
\hline & $10^{\text {th }}$ & 6 & 0.2 & 0.7 & 0.4 & 0.8 & 0.6 \\
\hline & $10^{\text {th }}$ & 10 & 0.2 & 0.5 & 0.5 & 0.3 & 0.2 \\
\hline & $10^{\mathrm{th}}$ & 30 & 0.4 & 2.3 & 0.5 & 1.0 & 0.2 \\
\hline & $10^{\text {th }}$ & 60 & 0.2 & 2.2 & 0.7 & 1.0 & 0.3 \\
\hline & $50^{\text {th }}$ & 60 & 0.9 & 3.7 & 2.0 & 0.9 & 0.5 \\
\hline \multirow[t]{7}{*}{$\mathrm{Pb}$} & & 0.01 & 0.4 & 0.3 & 0.2 & 0.3 & 0.2 \\
\hline & $10^{\mathrm{th}}$ & 0.05 & 0.3 & 1.2 & 0.8 & 0.7 & 0.3 \\
\hline & $10^{\text {th }}$ & 0.1 & 0.5 & 1.4 & 0.5 & 1.1 & 0.5 \\
\hline & $10^{\text {th }}$ & 0.5 & 0.1 & 1.7 & 0.7 & 0.9 & 0.6 \\
\hline & $10^{\text {th }}$ & 1 & 0.3 & 2.2 & 1.1 & 1.1 & 0.4 \\
\hline & $10^{\text {th }}$ & 2 & 0.1 & 2.4 & 0.2 & 1.3 & 0.1 \\
\hline & $50^{\text {th }}$ & 2 & 0.7 & 2.4 & 0.3 & 1.9 & 0.3 \\
\hline \multirow[t]{7}{*}{$\mathrm{Cu}$} & & 1 & 1.0 & 1.2 & 0.4 & 0.3 & 0.8 \\
\hline & $10^{\text {th }}$ & 2 & 0.9 & 1.9 & 0.3 & 1.5 & 0.9 \\
\hline & $10^{\mathrm{th}}$ & 5 & 1.1 & 1.9 & 0.2 & 1.3 & 1.1 \\
\hline & $10^{\text {th }}$ & 10 & 1.4 & 1.8 & 0.4 & 1.1 & 1.1 \\
\hline & $10^{\text {th }}$ & 15 & 1.7 & 2.0 & 0.7 & 1.3 & 2.2 \\
\hline & $10^{\text {th }}$ & 20 & 2.5 & 2.3 & 0.9 & 1.5 & 4.3 \\
\hline & $50^{\text {th }}$ & 20 & 4.8 & 2.1 & 1.2 & 2.6 & 4.2 \\
\hline \multirow[t]{7}{*}{$\mathrm{Mn}$} & & 0.01 & 1.6 & 0.5 & 0.4 & 0.5 & 0.9 \\
\hline & $10^{\text {th }}$ & 0.05 & 1.6 & 0.6 & 0.6 & 0.5 & 1.3 \\
\hline & $10^{\text {th }}$ & 0.1 & 1.6 & 0.8 & 0.5 & 0.7 & 1.9 \\
\hline & $10^{\text {th }}$ & 0.5 & 1.3 & 0.9 & 0.6 & 0.4 & 2.0 \\
\hline & $10^{\text {th }}$ & 1 & 1.1 & 1.5 & 0.2 & 1.0 & 2.8 \\
\hline & $10^{\text {th }}$ & 2 & 1.2 & 1.5 & 0.4 & 1.1 & 3.3 \\
\hline & $50^{\text {th }}$ & 2 & 1.3 & 2.1 & 1.1 & 1.1 & 2.8 \\
\hline
\end{tabular}

Note:

$\triangle E 2000:$ CIEDE2000

$\Delta E^{*}=$ total colour difference value

$\triangle E$ meaning:

0-1 meaning a normally invisible difference

1-2: very small invisible difference, only obvious to a trained eye

2-3.5: medium difference, also obvious to an untrained eye

3.5-5: an obvious difference

>6: a very obvious difference 


\section{Table 3}

Tensile strengths with $\mathrm{Cu}$ and $\mathrm{Mn}$, washing at $10^{\text {th }}$ wash cycle

\begin{tabular}{lcccccc}
\hline Water & Heavy metal & \multicolumn{5}{c}{ Cloth } \\
\cline { 3 - 6 } sources & conc. $(\mathbf{m g} / \mathbf{L})$ & $\mathbf{D}$ & $\mathbf{P o}$ & $\mathbf{P o C}$ & $\mathbf{S}$ & $\mathbf{C}$ \\
\hline Tap water & & $531^{\mathrm{a}} \pm 9.5$ & $315^{\mathrm{a}} \pm 3.9$ & $398^{\mathrm{ab}} \pm 10.5$ & $551^{\mathrm{a}} \pm 6.3$ & $151^{\mathrm{a}} \pm 6.3$ \\
& 1 & $520^{\mathrm{a}} \pm 13.5$ & $321^{\mathrm{a}} \pm 19.6$ & $392^{\mathrm{ab}} \pm 15.3$ & $549^{\mathrm{a}} \pm 17.1$ & $141^{\mathrm{abc}} \pm 11.5$ \\
Synthetic & 2 & $521^{\mathrm{a}} \pm 14.3$ & $283^{\mathrm{ab}} \pm 17.8$ & $400^{\mathrm{a}} \pm 19.2$ & $553^{\mathrm{a}} \pm 11.7$ & $138^{\mathrm{abc}} \pm 10.8$ \\
recycled & 5 & $513^{\mathrm{a}} \pm 14.3$ & $279^{\mathrm{ab}} \pm 17.3$ & $402^{\mathrm{ab}} \pm 13.9$ & $560^{\mathrm{a}} \pm 11.5$ & $151^{\mathrm{ab}} \pm 13.7$ \\
water with & 10 & $448^{\mathrm{b}} \pm 18.5$ & $274^{\mathrm{bc}} \pm 22.3$ & $390^{\mathrm{bc}} \pm 17.2$ & $510^{\mathrm{b}} \pm 20.8$ & $144^{\mathrm{abc}} \pm 11.8$ \\
Cu & 15 & $450^{\mathrm{b}} \pm 31.5$ & $259^{\mathrm{b}} \pm 15.6$ & $378^{\mathrm{cd}} \pm 18.8$ & $459^{\mathrm{c}} \pm 20.8$ & $137^{\mathrm{bc}} \pm 11.8$ \\
& 20 & $446^{\mathrm{b}} \pm 20.9$ & $257^{\mathrm{b}} \pm 25.4$ & $369^{\mathrm{d}} \pm 14.8$ & $462^{\mathrm{c}} \pm 11.9$ & $133^{\mathrm{c}} \pm 10.1$ \\
Synthetic & 0.05 & $531^{\mathrm{ab}} \pm 7.2$ & $313^{\mathrm{a}} \pm 6.6$ & $400^{\mathrm{a}} \pm 6.6$ & $551^{\mathrm{ab}} \pm 8.3$ & $148^{\mathrm{ab}} \pm 7.6$ \\
recycled & 0.1 & $527^{\mathrm{b}} \pm 6.7$ & $319^{\mathrm{a}} \pm 6.2$ & $402^{\mathrm{a}} \pm 6.3$ & $557^{\mathrm{a}} \pm 6.3$ & $151^{\mathrm{a}} \pm 6.4$ \\
water with & 0.5 & $538^{\mathrm{a}} \pm 6.3$ & $305^{\mathrm{b}} \pm 6.5$ & $395^{\mathrm{ab}} \pm 7.4$ & $547^{\mathrm{b}} \pm 4.0$ & $147^{\mathrm{ab}} \pm 7.3$ \\
Mn & 1 & $530^{\mathrm{ab}} \pm 6.8$ & $303^{\mathrm{b}} \pm 6.4$ & $389^{\mathrm{bc}} \pm 5.5$ & $498^{\mathrm{c}} \pm 6.8$ & $147^{\mathrm{ab}} \pm 7.0$ \\
& 2 & $516^{\mathrm{c}} \pm 4.4$ & $303^{\mathrm{b}} \pm 6.0$ & $381^{\mathrm{c}} \pm 5.3$ & $490^{\mathrm{c}} \pm 9.7$ & $139^{\mathrm{b}} \pm 8.3$ \\
\hline
\end{tabular}

Note: ${ }^{a, b, c, d}$ represents the group according to ANOVA-One way analysis (Tukey's test $p<0.05, n=11$ ). The values sharing the same alphabets represent no significant difference in tensile strength ( \pm values are the standard deviations) 
Table 4

LSI of aqueous solutions of various concentrations of various heavy metals

\begin{tabular}{|c|c|c|c|c|c|c|c|}
\hline Metals & $\begin{array}{l}\text { Conc. } \\
(\mathrm{mg} / \mathrm{l})\end{array}$ & $\begin{array}{l}\text { Ca hardness } \\
\mathrm{CaCO}_{3}(\mathrm{mg} / \mathrm{l})\end{array}$ & $\begin{array}{c}\text { Total } \\
\text { Alkalinity } \\
(\mathrm{mg} / \mathrm{l})\end{array}$ & pH & TDS & $\begin{array}{c}\text { Temp. } \\
\left({ }^{\circ} \mathrm{C}\right)\end{array}$ & LSI \\
\hline \multirow[t]{6}{*}{$\mathbf{F e}$} & 0.1 & 62.5 & 49 & 8.13 & 155 & 24 & -0.31 \\
\hline & 0.3 & 60.5 & 47 & 8.10 & 156 & 24 & -0.37 \\
\hline & 0.5 & 55 & 45 & 7.80 & 156 & 24 & -0.50 \\
\hline & 1 & 55 & 45 & 7.51 & 156 & 24 & -1.02 \\
\hline & 3 & 60 & 45 & 7.40 & 156 & 24 & -1.05 \\
\hline & 5 & 62.5 & 40 & 7.50 & 157 & 24 & -1.12 \\
\hline \multirow[t]{6}{*}{$\mathbf{Z n}$} & 1 & 85 & 40 & 8.30 & 157 & 24 & -0.09 \\
\hline & 3 & 84 & 40 & 8.19 & 159 & 24 & -0.21 \\
\hline & 6 & 86 & 40 & 8.10 & 159.5 & 24 & -0.29 \\
\hline & 10 & 85 & 45 & 7.90 & 161 & 24 & -0.44 \\
\hline & 30 & 85 & 40 & 7.80 & 176.5 & 24 & -0.60 \\
\hline & 60 & 87 & 40 & 7.40 & 190 & 24 & -0.99 \\
\hline \multirow[t]{6}{*}{$\mathbf{P b}$} & 0.01 & 75 & 40 & 8.20 & 155 & 24 & -0.24 \\
\hline & 0.05 & 70 & 40 & 8.20 & 155 & 24 & -0.28 \\
\hline & 0.1 & 75 & 40 & 8.20 & 155 & 24 & -0.25 \\
\hline & 0.5 & 77.5 & 40 & 8.10 & 155 & 24 & -0.34 \\
\hline & 1 & 80 & 40 & 8.20 & 155 & 24 & -0.22 \\
\hline & 2 & 84 & 40 & 8.20 & 155 & 24 & -0.20 \\
\hline \multirow[t]{6}{*}{$\mathrm{Cu}$} & 1 & 80 & 40.6 & 8.20 & 155 & 24 & -0.21 \\
\hline & 2 & 80 & 36.3 & 8.20 & 156 & 24 & -0.26 \\
\hline & 5 & 82 & 36 & 7.60 & 157 & 24 & -0.50 \\
\hline & 10 & 83 & 37.8 & 7.40 & 159 & 24 & -1.03 \\
\hline & 15 & 89 & 38 & 7.30 & 162 & 24 & -1.09 \\
\hline & 20 & 82 & 35 & 7.20 & 164 & 24 & -1.27 \\
\hline \multirow[t]{6}{*}{ Mn } & 0.01 & 62.5 & 45 & 8.21 & 155 & 24 & -0.21 \\
\hline & 0.05 & 60.5 & 45 & 8.12 & 155 & 24 & -0.28 \\
\hline & 0.1 & 55 & 46.8 & 7.90 & 155 & 24 & -0.50 \\
\hline & 0.5 & 55 & 45.9 & 8.21 & 155 & 24 & -0.24 \\
\hline & 1 & 60 & 46.8 & 7.94 & 155 & 24 & -0.46 \\
\hline & 2 & 62.5 & 45.9 & 7.81 & 155 & 24 & -0.60 \\
\hline
\end{tabular}


